\title{
A New Species and Combination in Central American Solanaceae
}

\author{
Lynn Bohs \\ Department of Biology, University of Utah, Salt Lake City, Utah 84112, U.S.A. \\ bohs@biology.utah.edu
}

Abstract. A new species of Solanum sect. Geminata (G. Don) Walp. (Solanaceae) from Costa Rica and Panama, S. sotobosquense Bohs, is described here from Limón, Costa Rica. It is morphologically most similar to $S$. rovirosanum Donn. Sm., but differs in its short, usually forked inflorescences and long fruiting pedicels. It has been named in honor of one of its collectors, D. Armando Soto, and in reference to its understory habitat. A new combination, Cuatresia cuneata (Standl.) Bohs, is also published here. Although based on the name Lycianthes cuneata Standl., this species has most commonly been considered to belong to the genus Witheringia L'Hér. Morphological and molecular data show that this species is a member of the genus Cuatresia Hunz., not Witheringia.

Resumen. Se describe aquí una especie nueva de Solanum sect. Geminata (G. Don) Walp. (Solanaceae), S. sotobosquense Bohs, de Limón, Costa Rica. Morfológicamente se parece a $S$. rovirosanum Donn. $\mathrm{Sm}$, pero se diferencia por sus inflorescencias cortas y normalmente bifurcadas, y los pedicelos largos en fructificación. Ha sido nombrada en honor de uno de sus colectores, D. Armando Soto, y en referencia a su hábitat en el sotobosque. También se publica aquí una combinación nueva, Cuatresia cuneata (Standl.) Bohs. Aunque fue basado en el nombre Lycianthes cuneata Standl., ésta especie ha sido considerada comúnmente un miembro del género Witheringia L'Hér. Los datos morfológicos y moleculares muestran que ésta especie pertenece al género Cuatresia Hunz., no a Witheringia.

Key words: Costa Rica, Cuatresia, IUCN Red List, Panama, Solanaceae, Solanum, sect. Geminata, Witheringia.

\section{A New Species of Solanum sect. Geminata}

Solanum L. (Solanaceae), with an estimated 1500 species, is one of the largest and most diverse genera of flowering plants (Frodin, 2004; Weese \& Bohs, 2007). Within this genus, some of the most difficult species to identify are members of Solanum sect. Geminata (G. Don) Walp., which comprise over 120 taxa centered in the Neotropics. Knapp monographed this section in 2002, but more species in this group have been discovered since the publication of her careful treatment (Knapp, 2005, 2008; Nee et al., 2006; Granados-Tochoy et al., 2007). Concurrently, molecular data are helping to define the limits of the section and the phylogenetic relationships among its species. Published molecular phylogenetic studies identify a strongly supported group called the Geminata clade that conforms in most part to the traditional circumscription of the section (Bohs, 2005; Weese \& Bohs, 2007; Knapp, 2008). Ongoing work is contributing to a detailed phylogeny of over half the species in the clade (Bohs et al., unpublished data). In addition, a large-scale project is underway to produce a species-level taxonomic treatment of the genus Solanum (Knapp et al., 2004; < http://www.nhm.ac. uk/solanaceaesource $>$ ). Together, all these activities are producing the most complete systematic picture of the genus Solanum ever attempted.

Work on the Solanaceae for the Manual de Plantas de Costa Rica (Bohs \& Soto, in prep.) shows that the flora of this rather small country includes over 70 species of Solanum. While doing research on this flora, a new species of Solanum sect. Geminata was discovered. It is described here and compared with similar Central American species of the section.

Solanum sotobosquense Bohs, sp. nov. TYPE: Costa Rica. Limón: P. N. Cordillera de Talamanca, Talamanca, sendero de Quebrada Kuisa a Río Lori, entre Ujarrás y San José de Cabécar, $09^{\circ} 21^{\prime} 00^{\prime \prime} \mathrm{N}, 83^{\circ} 13^{\prime} 20^{\prime \prime} \mathrm{W}, 2000 \mathrm{~m}, 16$ Mar. 1993 (fl., fr.), G. Herrera 5903 (holotype, INB; isotypes, BM, CR, MO, USJ, UT). Figures 1-3.

Solano rovirosano Donn. Sm. simile, sed ab eo inflorescentiis brevibus plerumque furcatis et pedicellis fructiferis longis differt.

Shrub or small tree up to $6 \mathrm{~m}$ tall; stems scurfy, the surface irregularly cracking and peeling into small white or pale yellowish horizontal plates; sympodial units difoliate, geminate. Leaves simple, dimorphic, the larger blades $19-35 \times 7-13 \mathrm{~cm}$, ca. $2-3 \times$ as long as wide, elliptic to obovate, the smaller blades 2.5-7 $\times 2-4 \mathrm{~cm}$, ca. $1-1.5 \times$ as long as wide, basically the same shape as the larger blades or somewhat more 


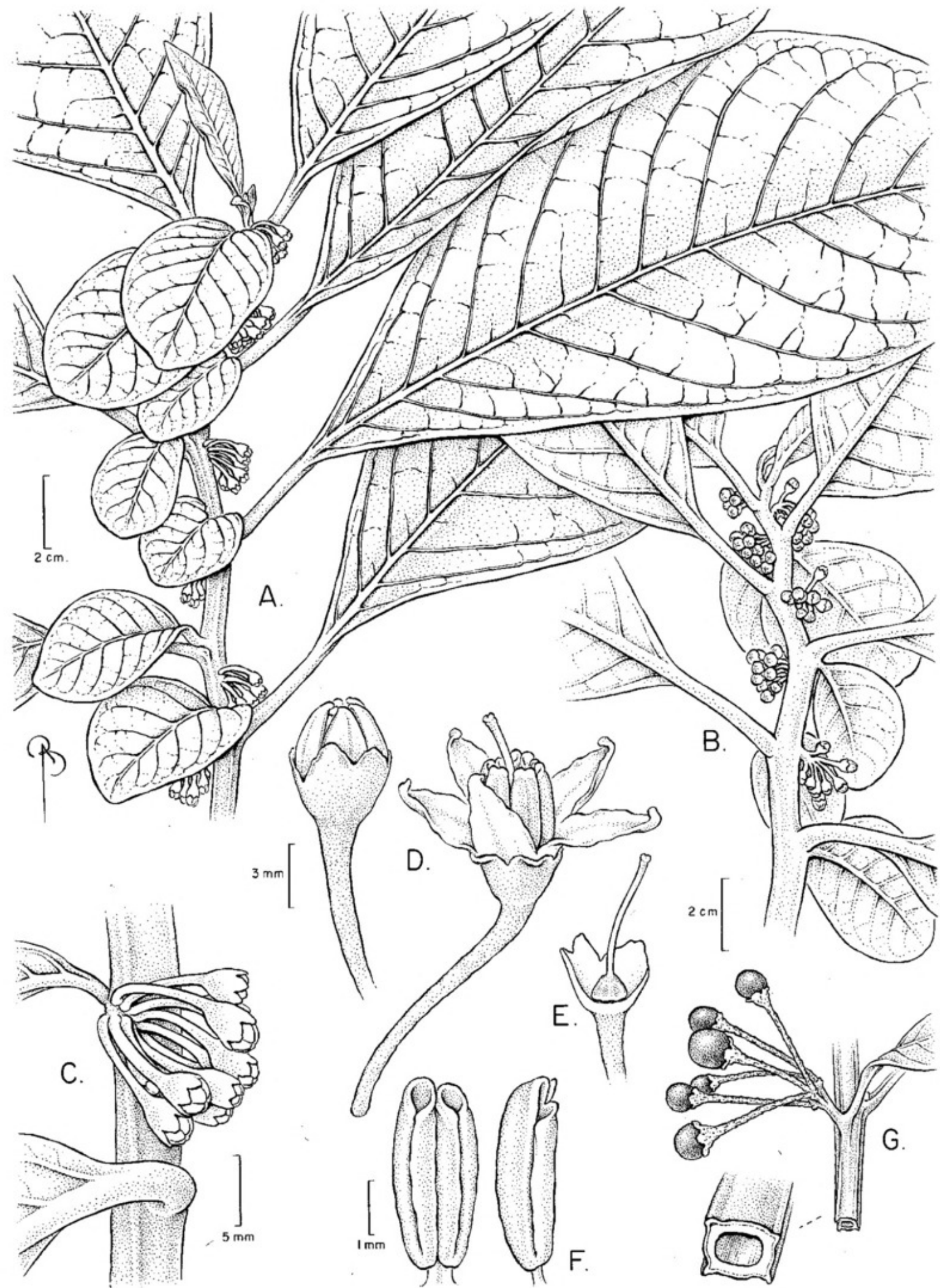

Figure 1. Solanum sotobosquense Bohs. - A, B. Habit. - C. Inflorescence. -D. Bud (left) and opened flower (right). -E. Gynoecium. -F. Stamens. - G. Infructescence and stem cross section. A-C from Soto et al. 1226 (NY); D-F from Hammel et al. 6493 (NY); G from Hammel 6077 (NY).

rounded, subcoriaceous to somewhat fleshy, glabrous or very sparsely glandular-puberulent adaxially, glabrous to moderately puberulent abaxially on leaf veins and mesophyll with unbranched and often gland-tipped hairs, the midrib scurfy; base cuneate to decurrent; margin entire; apex acute or obtuse; petioles $1-5 \mathrm{~cm}$, with scurfy surface like that of the stem. Inflorescences nearly sessile or up to $1 \mathrm{~cm}$, leaf- 


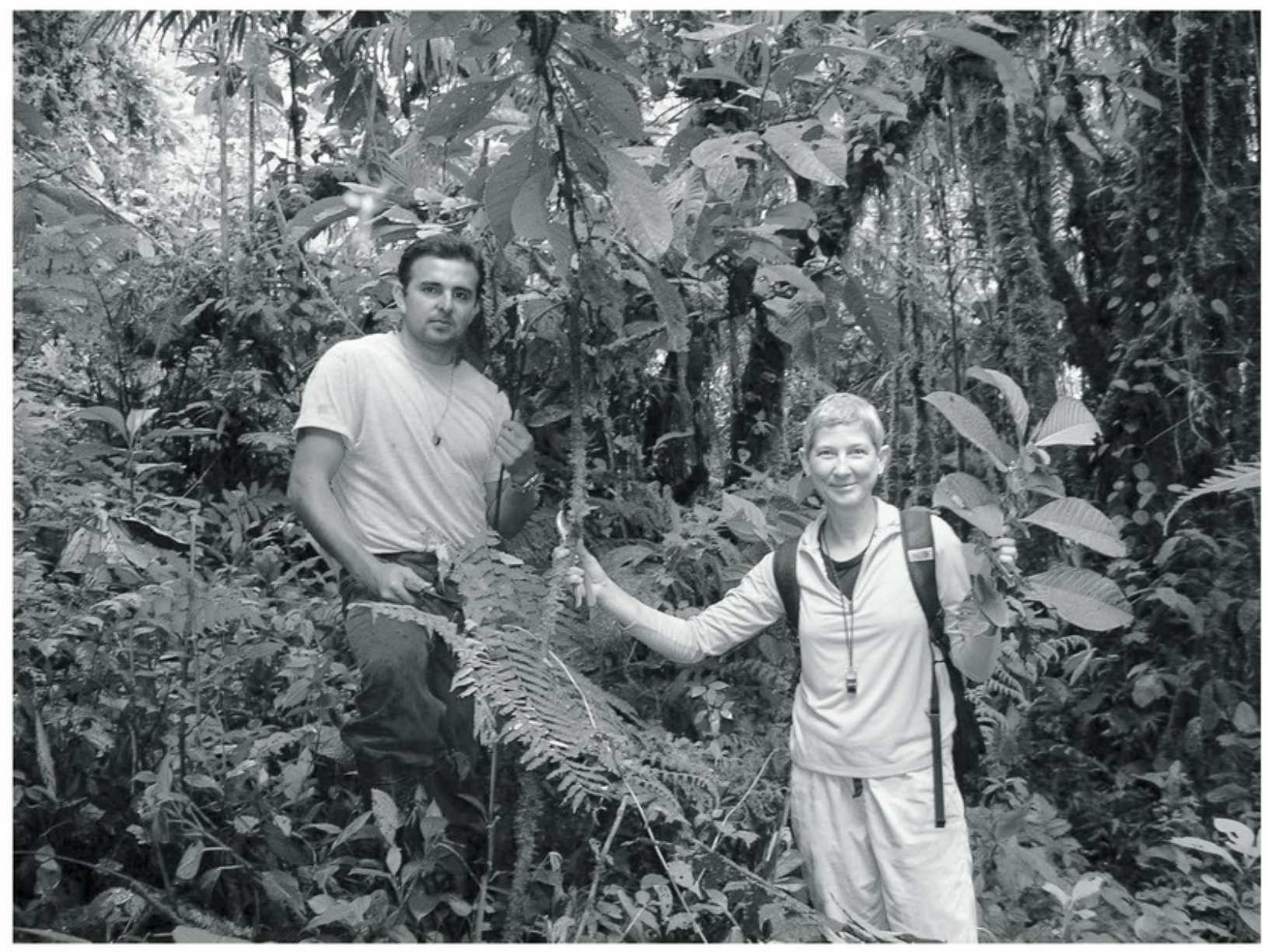

Figure 2. Armando Soto (left) and Lynn Bohs (right) with Solanum sotobosquense in the Parque Nacional Tapantí, Costa Rica.

opposed, usually forked, with 15 to $30+$ flowers, all flowers apparently perfect, the axes scurfy; peduncle $0.1-0.5 \mathrm{~cm}$; rachis $0.1-0.7 \mathrm{~cm}$; pedicels $10-18 \mathrm{~mm}$ in flower, 20-35 mm in fruit, erect, with corky thickenings, contiguous and overlapping, articulated at the base. Flowers with the calyx $3-4 \mathrm{~mm}$, the tube 1-2 mm, the lobes often unequal, $1-3 \times$ ca. $2 \mathrm{~mm}$, deltate, obtuse to mucronate at tips, glabrous to sparsely puberulent and often scurfy; fruiting calyx somewhat accrescent, the lobes ca. $3 \times 2.5-3 \mathrm{~mm}$, subtending but not covering the fruit; corolla $6-9 \mathrm{~mm}$, 1-2 cm diam., stellate, subcoriaceous or fleshy, white, the tube $1-1.5 \mathrm{~mm}$, the lobes $5-8 \times 2-3 \mathrm{~mm}$, lanceolate, glabrous abaxially and adaxially; stamens equal, with filaments connate at base, the tube ca. 1 $\mathrm{mm}$, the free part $0.5-1 \mathrm{~mm}$; anthers $3-4 \times$ ca. 1.5 $\mathrm{mm}$, oblong, not connivent, yellow, the pores large, directed distally, opening into longitudinal slits with age; ovary densely puberulent; style $4-7 \times 0.2-0.4$ $\mathrm{mm}$, cylindrical, straight; stigma capitate. Fruits 0.6$1 \mathrm{~cm}$ diam., globose, green, densely glandular- and eglandular-puberulent when young, glabrous when older, held upright; seeds ca. $2 \times 2 \mathrm{~mm}$, ovoidreniform, dark brown, the surface nearly smooth.
Distribution, habitat, and phenology. The new species is an uncommon understory shrub or small tree in rainforests and cloud forests of the Cordillera de Talamanca of southern Costa Rica and adjacent parts of Chiriquí Province, Panama, at 1500-2100 m in elevation. Flowering specimens have been collected in January, March, April, June, and November; fruiting specimens have been collected in February, March, and May.

IUCN Red List category. According to the IUCN Red List criteria (IUCN, 2001), Solanum sotobosquense is classified as VU Bla+2a; D1 (Vulnerable; extent of occurrence less than $20,000 \mathrm{~km}^{2}$ and area of occupancy less than $2000 \mathrm{~km}^{2}$, populations severely fragmented and known to exist at fewer than 10 locations, and population size estimated to number fewer than 1000 individuals). Populations of this species occur in protected areas of Parque Nacional Tapantí in Costa Rica and Parque Internacional La Amistad in Costa Rica and Panama and therefore are not perceived to be under direct threat at present.

Etymology. The epithet describes the habitat of this species, in the forest understory ("sotobosque" in 


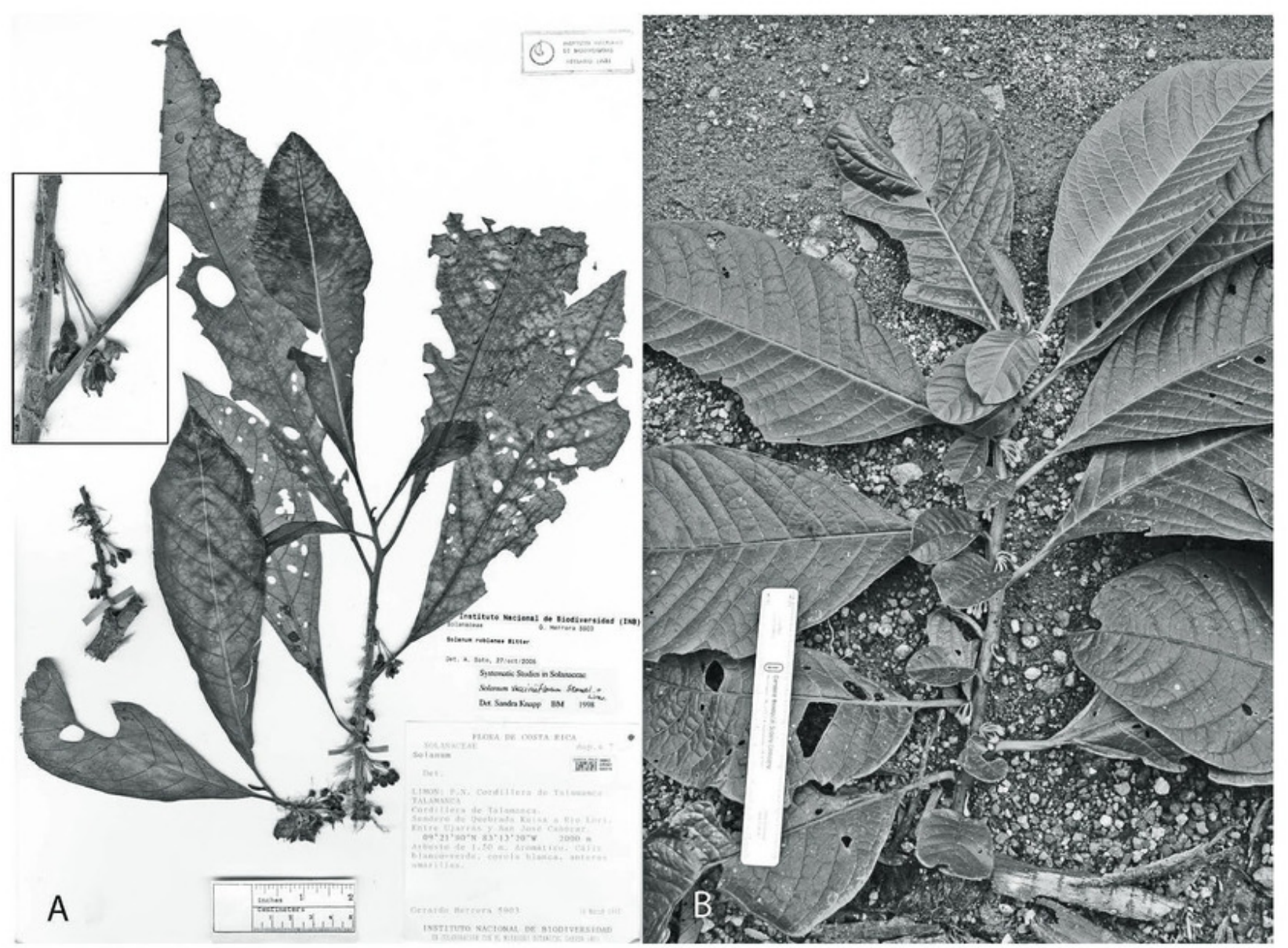

Figure 3. - A. Holotype of Solanum sotobosquense Bohs (Herrera 5903, INB). Inset: inflorescence detail. -B. Branch of $S$. sotobosquense showing paired (geminate) unequal leaves typical of the $S$. arboreum species group of Knapp (2002).

Spanish). It also commemorates Armando Soto, a Costa Rican Solanaceae specialist who guided the author to a population of this species in Parque Nacional Tapantí, Costa Rica.

Discussion. Specimens of this new taxon have been identified as Solanum arboreum Dunal, $S$. narcoticosmum Bitter, $S$. roblense Bitter, and $S$. vacciniiflorum Standl. \& L. O. Williams by S. Knapp (pers. comm.) and others, but these specimens do not fit with the descriptions of any of those species. Solanum sotobosquense is densely puberulent on the new growth with minute glandular hairs and the leaf veins and mesophyll beneath are pubescent with unbranched, often gland-tipped hairs; the new growth and leaves of $S$. narcoticosmum are glabrous. It differs from S. arboreum in being a shrub or small tree (vs. a rhizomatous shrub). Its minutely glandular-puberulent fruits and large flowers distinguish it from $S$. roblense. Solanum sotobosquense lacks the distinctive hairs with reddish cross walls found in $S$. vacciniiflorum; the smaller, bullate leaves and deflexed fruiting pedicels of the latter species also help to distinguish the two species. The very long (20-35 $\mathrm{mm}$ ), erect fruiting pedicels of $S$. sotobosquense differ from all the species mentioned above. Solanum arboreum, S. narcoticosmum, and $S$. roblense have erect fruiting pedicels up to about $20 \mathrm{~mm}$ long (to 25 $\mathrm{mm}$ in S. narcoticosmum; Knapp, 2002). The fruiting pedicels of S. vacciniiflorum range from 18 to $30 \mathrm{~mm}$ long, approaching the length of those of $S$. sotobosquense, but they are deflexed rather than erect.

Morphologically, Solanum sotobosquense is most similar to $S$. rovirosanum Donn. Sm. due to its large leaves, but the new species differs in its short, usually forked inflorescences (up to $1 \mathrm{~cm}$ long in $S$. sotobosquense vs. $1.5-8 \mathrm{~cm}$ long and often highly branched in S. rovirosanum) and long fruiting pedicels (20-35 mm long in S. sotobosquense vs. 8-13 mm long in $S$. rovirosanum).

Solanum sotobosquense exhibits a number of characters found in Knapp's $S$. arboreum species group, such as difoliate and geminate sympodial units with strongly dimorphic leaves, short inflorescences with overlapping pedicel scars, and erect fruiting pedicels. At least three other species of this group, $S$. arboreum, S. ramonense C. V. Morton \& Standl., and S. roblense, have similar scurfy stems, major leaf veins, and inflorescence axes, where the surface cracks and 
peels into small plates. Molecular data (Bohs et al., unpublished) indicate that $S$. sotobosquense may be most closely related to $S$. arboreum, $S$. ramonense, and $S$. roblense and is only distantly related to $S$. rovirosanum despite its morphological similarity to the latter species.

Paratypes. COSTA RICA. Cartago: ca. $15 \mathrm{~km} \mathrm{~S}$ of Tapantí along new rd. on E slope above Río Grande de Orosí near concrete bridge, $09^{\circ} 42^{\prime} \mathrm{N}, 83^{\circ} 47^{\prime} \mathrm{W}, 1500 \mathrm{~m}, 13$ Mar. \& 14 Apr. 1973 (fl.), J. L. Gentry \& W. C. Burger 2636 (MO); Parque Nac. Tapantí, Río Dos Amigos at river crossing on second concrete bridge, $1600 \mathrm{~m}, 9^{\circ} 41^{\prime} 38.9^{\prime \prime} \mathrm{N}$, 8346'58.6" W, 11 Jan. 2006 (fl.), D. A. Soto, L. Bohs \& J. Sperry 1226 (INB, MO, NY, UT). PANAMA. Chiriquí: vic. of Boquete, Cerro Pate de Macho, upper NE slopes \& along soggy ridge of Cont. Divide, $08^{\circ} 46^{\prime} \mathrm{N}, 82^{\circ} 25^{\prime} \mathrm{W}, 1900-2000$ m, 19 June 1987 (fl.), T. Croat 66446 (NY); region of Boquete, Cerro Horqueta, $6500 \mathrm{ft}$., 8 May 1940 (fr.), C. \& W. von Hagen 2084 (MO, NY); along trail from end of Río Palo Alto rd. to Chiriquí border with Bocas del Toro Prov. near peak of Cerro Pate Macho, $6200 \mathrm{ft} ., 20$ Nov. 1978 (fl.), B. Hammel 5820 (NY); NE of Boquete, end of rd. past Palo Alto along trail to Bocas past Cerro Pate Macho, 6200-6500 ft., 9 Feb. 1979 (fr.), B. Hammel 6077 (NY); end of rd. past Palo Alto to Bocas, 6500 ft., 18 Mar. 1979 (fl., fr.), B. Hammel et al. 6493 (MO, NY); trail to Cerro Pate Macho, headwaters of Río Palo Alto, above Palo Alto, $08^{\circ} 47^{\prime} \mathrm{N}$, $82^{\circ} 22^{\prime} \mathrm{W}, 1700-2100$ m, 15 Mar. 1982 (fl.), S. Knapp, W. J. Kress \& B. Hammel 4265 (NY); rd. to Cerro Punta Natl. Park from Alto Quiel \& Boquete, $08^{\circ} 51^{\prime} \mathrm{N}, 82^{\circ} 29^{\prime} \mathrm{W}$, ca. 1850 m, 16 Jan. 1986 (fl.), G. McPherson 8040 (NY).

\section{Transfer of WitheringIA CUNEATA to CUATRESIA}

The tribe Physaleae Miers of the Solanaceae includes about 200 species divided into approximately 25 genera (Olmstead et al., 2008). Generic circumscriptions and phylogenetic relationships within this group have been uncertain, and taxonomic concepts have varied widely among previous workers. For instance, Hunziker (2001) placed Cuatresia Hunz. and Witheringia L'Hér. together with seven other genera in subtribe Witheringinae. However, recent molecular analyses show that Cuatresia and Witheringia are clearly distinct phylogenetically (Olmstead et al., 2008). The species commonly known as W. cuneata (Standl.) Hunz. was included in this study, and it emerged in a strongly supported clade with C. exiguiflora (D'Arcy) Hunz. and C. riparia (Kunth) Hunz. and not with the other four species of Witheringia sequenced. Furthermore, the glabrous and somewhat rubbery-textured leaves of $W$. cuneata are typical of species of Cuatresia, as are the dull yellow coriaceous corollas. It is thus clear that $W$. cuneata should be transferred to the genus Cuatresia.

Cuatresia cuneata (Standl.) Bohs, comb. nov. Basionym: Lycianthes cuneata Standl., Publ. Field Columbian Mus., Bot. Ser. 4(8): 260.
1929. Witheringia cuneata (Standl.) Hunz., Kurtziana 5: 118. 1969. TYPE: Panama. Bocas del Toro: Research Lagoon, region of Almirante, Jan.-Mar. 1928, G. P. Cooper 405 (holotype, F 579181; isotypes, K, NY, US).

Acknowledgments. I thank A. Soto, J. Sperry, and B. Hammel for field assistance in Costa Rica; A. Soto, B. Hammel, and J. Sperry for photos and scans; J. C. Granados-Tochoy, A. Gutiérrez, R. Levin, N. Myers, and S. Stern for laboratory assistance; R. G. Olmstead for collaboration on the Cuatresia molecular work; S. Knapp for expert advice about Solanum sect. Geminata; Patricia Eckel (MO) for correcting the Latin diagnosis; and Bobbi Angell for the beautiful drawing. This work was supported by the National Science Foundation Planetary Biodiversity Inventory (grant DEB-0316614 "PBI Solanum-A worldwide treatment").

\section{Literature Cited}

Bohs, L. 2005. Major clades in Solanum based on $n d h \mathrm{~F}$ sequence data. Pp. 27-49 in R. C. Keating, V. C. Hollowell \& T. B. Croat (editors), A Festschrift for William G. D'Arcy: The Legacy of a Taxonomist. Monogr. Syst. Bot. Missouri Bot. Gard. 104.

Frodin, D. G. 2004. History and concepts of big plant genera. Taxon 53: 753-776.

Granados-Tochoy, J. C., S. Knapp \& C. I. Orozco. 2007. Solanum humboldtianum (Solanaceae): An endangered new species from Colombia rediscovered 200 years after its first collection. Syst. Bot. 32: 200-207.

Hunziker, A. T. 2001. Genera Solanacearum: The Genera of Solanaceae Illustrated, Arranged According to a New System. A. R. G. Gantner Verlag, Ruggell, Liechtenstein.

IUCN. 2001. IUCN Red List Categories and Criteria, Version 3.1. Prepared by the IUCN Species Survival Commission. IUCN, Gland, Switzerland, and Cambridge, United Kingdom.

Knapp, S. 2002. Solanum section Geminata (Solanaceae). Flora Neotropica Monograph 84. New York Botanical Garden, Bronx, New York.

Knapp, S. 2005. Taxonomic additions for Solanum section Geminata (Solanaceae) in Peru. Ann. Missouri Bot. Gard. 92: 248-253.

Knapp, S. 2008. A revision of the Solanum havanense species group and new taxonomic additions to the Geminata clade (Solanum: Solanaceae). Ann. Missouri Bot. Gard. 95: 405-458.

Knapp, S., L. Bohs, M. Nee \& D. M. Spooner. 2004. Solanaceae-A model for linking genomics with biodiversity. Comp. Funct. Genomics 5: 285-291.

Nee, M., L. Bohs \& S. Knapp. 2006. New species of Solanum and Capsicum (Solanaceae) from Bolivia, with clarification of nomenclature in some Bolivian Solanum. Brittonia 58: 322-356.

Olmstead, R. G., L. Bohs, H. A. Migid, E. SantiagoValentin, V. F. Garcia \& S. M. Collier. 2008. A molecular phylogeny of the Solanaceae. Taxon 57: 1159-1181.

Weese, T. L. \& L. Bohs. 2007. A three gene phylogeny of the genus Solanum (Solanaceae). Syst. Bot. 32: 445-463. 


\section{$2 \mathrm{BHL}$ Biodiversity Heritage Library}

Bohs, Lynn. 2011. "A New Species and Combination in Central American Solanaceae." Novon a journal of botanical nomenclature from the Missouri Botanical Garden 21(1), 23-27. https://doi.org/10.3417/2009019.

View This Item Online: https://www.biodiversitylibrary.org/item/180102

DOI: https://doi.org/10.3417/2009019

Permalink: https://www.biodiversitylibrary.org/partpdf/218449

\section{Holding Institution}

Missouri Botanical Garden, Peter H. Raven Library

\section{Sponsored by}

Missouri Botanical Garden

\section{Copyright \& Reuse}

Copyright Status: Permission to digitize granted by rights holder

Rights: https://www.biodiversitylibrary.org/permissions

This document was created from content at the Biodiversity Heritage Library, the world's largest open access digital library for biodiversity literature and archives. Visit BHL at https://www.biodiversitylibrary.org. 